\section{Basic components of a national blood system}

\author{
José Ramiro Cruz'1
}

Key words: blood donors, blood transfusion, health services, guidelines.

\footnotetext{
1 Pan American Health Organization, Laboratory and Blood Services, Washington, D.C., United States of America. Send correspondence to: José Ramiro Cruz, Laboratory and Blood Services, Pan American Health Organization, 525 23rd Street, N.W., Washington, D.C. 20037, United States of America; telephone: (202) 974-3230; fax: (202) 9743610; e-mail: cruzjose@paho.org
}

Blood transfusions are used to treat patients with serious medical conditions that cannot be corrected by other means (1). Despite the availability of certain blood substitutes that make it possible to maintain the volume or the consistency of circulating blood $(2,3)$, the biological activity of cellular and plasma components makes these the most efficient treatment for a number of clinical conditions (4-6).

The mission of a nation's blood services is to collect and prepare safe blood products in an efficient and timely manner and to appropriately transfuse them (7). Blood services include health facilities and centers that collect, process, store, and transfuse blood and blood components. Blood services may be run by the ministry of health, the social security system, the armed forces, the private sector, or nongovernmental organizations. For their part, transfusion services are part of health care facilities, usually hospitals.

The role of blood services includes educating, recruiting, selecting, retaining, and registering blood donors; collecting blood; processing blood into its components; performing serological and hematological analyses on the blood; storing the blood, releasing it, and transfusing it to patients who need a blood component; and evaluating the impact of those transfusions on the health of the recipients (7). Multiple institutions are involved in collecting, processing, and transfusing blood as well as in the wide range and variety of functions that blood services must perform. Therefore, to accomplish their mission, a country's blood services must be structured and organized in a manner-a national blood system-that assures the efficient use of donated blood and other resources and that also minimizes any potential untoward effect on the donors, the patients, and the blood services staff.

Donated blood must be considered a national resource that is provided voluntarily by healthy, socially committed individuals. Therefore, a blood system must prevent commercial exploitation of blood products and profit-making by blood services. It is the responsibility of the State to guarantee the availability of and access to safe blood in sufficient quantities for those who need it. The ministers of health of the Region of the Americas endorsed these concepts and outlined the principles of a national blood program in a resolution that the Directing Council of the Pan American Health Organization (PAHO) adopted in 1999 (Appendix 1). In developing and implementing a national blood 
policy, national health officials must take into consideration numerous legal, organizational, operational, financial, medical, and technical issues. Some of the basic components of a national blood system are discussed below to help those who are involved in planning, developing, implementing, and evaluating national blood systems, and to put into perspective the other articles on blood banks and blood services in the Region of the Americas that are included in this issue of the Revista Panamericana de Salud Pública/Pan American Journal of Public Health.

\section{LEGAL ASPECTS}

The legal framework for a blood system expresses the national blood policy and describes mechanisms governing the collection, processing, and transfusion of blood. It is the responsibility of the national legislature to enact this basic legal documentation.

Legislation surrounding blood systems should not favor or protect any given profession, institution, association, or organization, whether public or private or national or international. Instead, the legislation should seek national sufficiency, the highest possible blood safety and quality, appropriate access and availability for those who need it, and the efficient use of resources.
Table 1 presents a summary of the main purposes of blood transfusion legislation as well as the norms and the standard operating procedures for the blood system.

Through its department (or unit, program, etc.) of blood services, the ministry of health produces the norms for the registry, licensing, and operation of centers that will collect, process, and transfuse blood (Table 1). These norms are the requirements that blood services must fulfill in order to be able to operate within the framework of the national blood policy. Each blood service must establish and document the procedures that it will perform in order to accomplish its mission, to comply with the norms, and to follow the national blood policy.

\section{ORGANIZATIONAL, OPERATIONAL, AND FINANCIAL ASPECTS}

The mission of blood services is complex. First, the temporal and geographic needs for blood components must be known with a degree of certainty in order to prepare all components in sufficient quantities to make them available in a timely manner. The limited shelf life of the units of platelets and red blood cells must be taken into consideration in order to minimize waste. This requires a constant and well-planned supply of donors; having those donors necessitates ongoing contact with

TABLE 1. Main purposes of the legislation, norms, and standard operating procedures for a nation's blood system

\begin{tabular}{|c|c|c|}
\hline Item & Responsible entity & Purpose \\
\hline Legislation & $\begin{array}{r}\text { National assembly/ } \\
\text { congress/senate }\end{array}$ & $\begin{array}{l}\text { 1. Establish framework to promote: } \\
\text { - national sufficiency of blood } \\
\text { - efficient collection of blood } \\
\text { - timely availability of blood } \\
\text { - appropriate use of blood } \\
\text { 2. Protect the health and rights of donors } \\
\text { 3. Protect patients who need and/or receive blood, by assuring quality, safety, } \\
\text { and accessibility } \\
\text { 4. Protect blood for transfusion as a national resource and prevent its } \\
\text { commercial exploitation, by promoting voluntary blood donation and by } \\
\text { processing and transfusing blood in a nonprofit mode } \\
\text { 5. Assure the appropriate use of the resources allocated to blood services }\end{array}$ \\
\hline Norms & $\begin{array}{l}\text { Ministry of health program/ } \\
\text { office/unit/department of } \\
\text { blood services }\end{array}$ & $\begin{array}{l}\text { 1. Establish requirements for the operation of blood collection, blood processing, } \\
\text { blood storage, and blood transfusion services } \\
\text { 2. Establish requirements for quality, safety, and accessibility of blood } \\
\text { 3. Establish processes, procedures, mechanisms, and instruments to assess } \\
\text { compliance with requirements } \\
\text { 4. Establish consequences for noncompliance } \\
\text { 5. Define roles and responsibilities of institutions, departments, offices, } \\
\text { organizations, and individuals involved in blood services }\end{array}$ \\
\hline $\begin{array}{l}\text { Standard operating } \\
\text { procedures }\end{array}$ & Each blood service & $\begin{array}{l}\text { 1. Operationalize norms } \\
\text { 2. Facilitate training of personnel } \\
\text { 3. Facilitate audits }\end{array}$ \\
\hline
\end{tabular}


groups of persons who are likely to donate blood voluntarily and who have a low risk of transfusiontransmitted infections. Educating the general public is key to voluntary nonremunerated altruistic blood donation. The participation of educators, anthropologists, communicators, social marketers, and community leaders is vital in recruiting blood donors. The ministry of health must coordinate the national efforts in this area.

Blood collection should be planned so as to place the smallest burden possible on donors. Collection hours and sites must be organized in a way that encourages voluntary blood donation. Extended operating hours, collection centers outside hospitals, and extramural teams that come to worksites, public spaces, and other places where the public gathers must all be part of a donor-friendly approach.

Blood units must be processed shortly after collection. Separation into components is vital not only for better patient care but also for improved efficiency, as red blood cells, platelets, and plasma must be kept at different temperatures to maintain their biological activity. Immediate screening for infectious agents results in better use of platelets and reduces the likelihood of transfusing blood that is positive for infectious markers. Those processes are best carried out in facilities that handle a large number of units rather than in centers that process just a few thousand units per year (8). Once separated and screened, blood products must be made available to transfusion services so as to meet the needs of patients. Clear criteria must exist to determine the quantity and characteristics of the components that the processing centers give to each transfusion service.

Resources-human, infrastructure, and basic supplies-are needed to promote voluntary blood donation; to collect, process, store, deliver, and transfuse blood; and to assess the impact of blood services. Cost analyses are required to allocate sufficient funds to ensure proper operation of the system, to determine its efficiency, and to recover fees from the transfusion centers for the expenses involved in collecting and processing blood units.

Figure 1 and Table 2 summarize the recommended structural and functional relations among stakeholders concerned with blood availability, quality, and safety.

FIGURE 1. Organizational structure of a national blood system

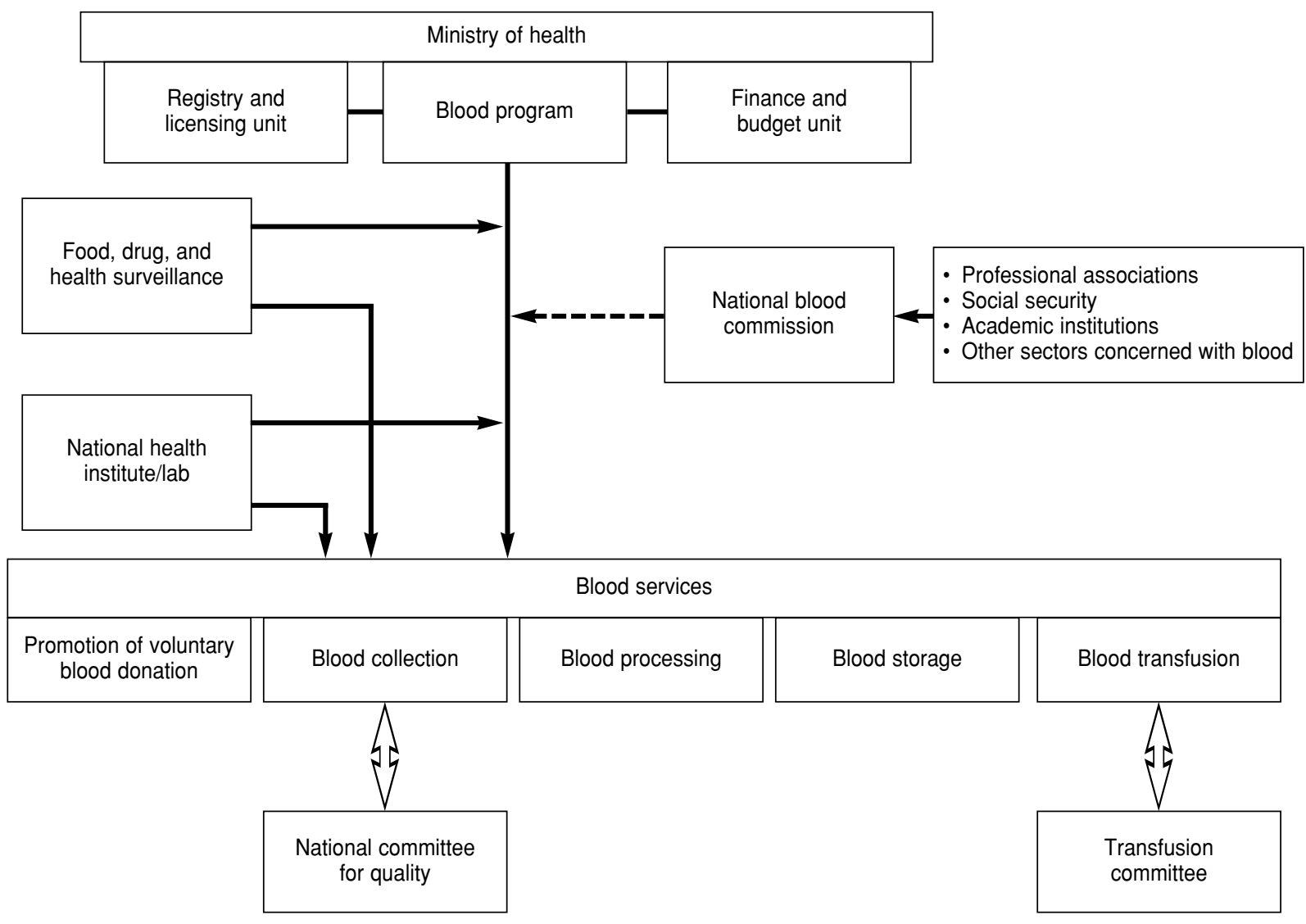


TABLE 2. Roles and functions of the various stakeholders concerned with blood availability, quality, and safety in a national blood system

\begin{tabular}{|c|c|}
\hline Stakeholder & Role/Function \\
\hline 1. Ministry of health & $\begin{array}{l}\text { Define national blood policy and plan } \\
\text { Allocate resources } \\
\text { Define roles } \\
\text { Sign agreements with other sectors and institutions involved in } \\
\text { blood services } \\
\text { Appoint personnel/advisors to the MOH blood program }\end{array}$ \\
\hline a. National blood program & $\begin{array}{l}\text { Implement blood policy and blood plan } \\
\text { Define norms } \\
\text { Define goals, needs, and indicators } \\
\text { Collect, validate, and analyze national data } \\
\text { Disseminate information } \\
\text { Oversee technical, scientific, medical, and administrative capacity } \\
\text { of blood services }\end{array}$ \\
\hline b. Registry and licensing unit & Audit services \\
\hline c. Finance and budget unit & Allocate funds \\
\hline 2. National or central laboratory/institute of health & External evaluation of performance \\
\hline 3. Food, drug, and health surveillance & Audit services \\
\hline $\begin{array}{l}\text { 4. National blood commission (all sectors involved in blood } \\
\text { services, including professional associations and academic } \\
\text { institutions) }\end{array}$ & $\begin{array}{l}\text { Technical advisor to the national blood program on: } \\
\text { - promotion of voluntary blood donation } \\
\text { - quality assurance } \\
\text { - use of blood } \\
\text { - cost analysis } \\
\text { organization and function of the national system }\end{array}$ \\
\hline 5. National committee for quality & $\begin{array}{l}\text { Define national standards } \\
\text { Develop training materials }\end{array}$ \\
\hline 6. Academic institutions & $\begin{array}{l}\text { Train personnel } \\
\text { Promote voluntary blood donation } \\
\text { Participate in the national blood commission }\end{array}$ \\
\hline 7. Professional associations & $\begin{array}{l}\text { Propose norms, standards } \\
\text { Provide continuing education } \\
\text { Participate in the national blood commission }\end{array}$ \\
\hline 8. Institutional blood transfusion committee & $\begin{array}{l}\text { Define institutional guidelines and needs for components } \\
\text { Provide hemovigilance }\end{array}$ \\
\hline
\end{tabular}

\section{MEDICAL AND TECHNICAL ASPECTS}

Blood transfusion is a medical procedure, so its prescription and consequences are the responsibility of the medical profession. Clinical criteria need to be taken into account when considering transfusion for a patient. Nevertheless, general guidelines are useful in standardizing transfusion practices within an institution or for given groups of patients. Such guidelines also make it easier to estimate the blood-component needs for an institution or a group of patients. A transfusion committee (TC) must develop appropriate general guidelines for the use of blood for that institution's patients. The TC must monitor adherence to those guidelines by the prescribing physicians as well as the impact that those guidelines and the resulting medical practices have on the health of the patients and on the efficiency of the transfusion service. Since transfusion services are not involved in blood collection and processing, the TC must determine both the quantities of blood components required and their specific characteristics. This can include, for example, leukoreduced, irradiated, or cytomegalovirus-negative 
units. The TC must also set the criteria for quality that will be applied when obtaining the blood components from the processing service.

Based on the information from each institution that transfuses blood, the national blood program estimates the blood required to cover national needs and develops a plan to collect enough blood units to satisfy those needs (Table 2). The plan must consider the proportion of potential donors who will be deferred, the prevalence of infectious markers among the donor population, the number of units that are not appropriate for transfusion (due to the presence of infectious agents, hemolysis, insufficient volume, or other factors), and the number of units that will become outdated. Unforeseen emergency situations should also be included in the equation. Once those steps are taken, it will be possible to determine the required funds and the specific needs for such supplies as blood collection bags and blood testing kits.

A national blood program must develop a plan to recruit enough donors to meet the national need for blood components. For that, it is necessary to understand the local epidemiology of risk behaviors and factors that will determine deferral of potential donors, in order to better target population groups with low risk levels. Cultural and social issues are important factors in the success of recruitment efforts. Once the reasons for deferral are clearly identified, the national blood program must ensure that the persons who interview potential donors understand the rationale behind each question and the implications of each possible answer. Those who interview and evaluate donors do not need to be physicians, but they must work under the supervision of a medically trained individual. Donor recruitment and blood collection centers must have standard operating procedures in place, and they must be subjected to audits.

Blood processing centers need to be informed about the national needs for blood, and each center must define what contribution it will make to the system. The requirements that the collection center must fulfill in receiving blood units and processing them must be clearly stated. Information on the quantities and specifications of the materials, supplies, general support facilities, and personnel needed for universal, efficient, precise, and timely processing of blood units need to be identified by the ministry of health and provided to the processing centers. Analyses of communication and transport facilities, cost efficiency, and blood-component shelf life must be considered when planning the functional relationship among collection, processing, and transfusion services. Processing centers must be subjected to audits, and they must participate in external performance evaluations.
There should be a national blood commission that plays a central role as an advisory body to the ministry of health, in planning and evaluating the national blood system (Table 2). While the commission is headed by the national blood program of the ministry of health, it must also have representation from all the other sectors and institutions involved with blood services in the country. Within the advisory body, it is desirable to have individuals who are specifically responsible for the promotion of voluntary blood donation as well as for quality assurance, the clinical use of blood, and cost analyses. The commission may provide recommendations on criteria for donor selection, for screening tests, and for characteristics of blood components. Additionally, this advisory body may evaluate the strategies and mechanisms for improving the efficiency of the national blood policy and plan.

As stated in the PAHO resolution on blood banks (Appendix 1), national blood programs should assure adequate quality. To do this, there must be quality control, external evaluation of performance, audits, and continuing education for blood services personnel. To improve the quality of services and of blood components, there must be both quality standards and national institutions that perform the external performance evaluations, by using audits and panels of unknown samples. The ongoing training of blood services personnel must be planned and supported by blood services. That education should be provided in conjunction with professional associations and academic institutions.

\section{SINOPSIS}

\section{Componentes básicos de un sistema nacional de servicios de sangre}

En este artículo se resumen la misión y las funciones de los servicios de sangre de un país y se examinan los componentes necesarios para el funcionamiento adecuado y eficiente de un sistema nacional de servicios de sangre. La sangre para transfusión es un recurso nacional $y$, por tanto, las autoridades sanitarias deben garantizar su disponibilidad, seguridad, calidad y uso eficiente. Para alcanzar estas metas, cada país debe tener un marco jurídico reglamentario para los centros donde se extrae, procesa y transfunde la sangre. Las leyes y los reglamentos sirven de base para la organización del sistema de servicios nacional, identifican las tareas de los interesados directos y garantizan la disponibilidad de los recursos que necesita el sistema. Esas leyes y reglamentos deben basarse en sólidos criterios médicos y técnicos. Dentro de este marco, es importante tener presentes las diversas funciones de los distintos departamentos del ministerio de salud, así como de otras instituciones, organizaciones no gubernamentales y grupos académicos y de los profesionales vinculados con el sistema nacional de servicios de salud. 


\section{REFERENCES}

1. World Health Organization. The clinical use of blood in medicine, obstetrics, paediatrics, surgery \& anaesthesia, trauma \& burns. Geneva: WHO; 1999.

2. Lowe KC. Substitutes for blood. Expert Opin Pharmacother 2001;2(7):1057-1059.

3. Winslow RM. Blood substitutes: refocusing an elusive goal. J Haematol 2000;111: 387-396.
4. Riess JG. Oxygen carriers ("blood substitutes") - raison d'etre, chemistry, and some physiology. Chem Rev 2001;101:2797-2920.

5. Burris D. Blood substitutes in surgery. Ann Chir Gynaecol 2001;90(2):76-80.

6. de Jonge E, Levi M. Effects of different plasma substitutes on blood coagulation: a comparative review. Crit Care Med 2001;29:1261-1267.
7. Emmanuel JC. Servicios o sistemas nacionales de sangre. Políticas, planes y programas nacionales. Rev Arg Transf 1999; 4:301-304.

8. Beltrán Durán $M$, Ayala Guzmán $M$. Evaluación externa de los resultados serológicos en los bancos de sangre de Colombia. Rev Panam Salud Publica 2003;13(2-3):138-143.

\section{APPENDIX 1. Resolution CD41.R15 approved by the 41st Directing Council of the Pan American Health Organization, San Juan, Puerto Rico, October 1999}

\section{STRENGTHENING BLOOD BANKS IN THE REGION OF THE AMERICAS}

THE 41ST DIRECTING COUNCIL,

Considering that the transfusion of blood products is a medical procedure performed for the treatment of patients with serious illness or emergencies that cannot be treated by other means;

Affirming that it is the inescapable responsibility of the health systems and services to guarantee the efficient processing, adequate supply, and timely delivery of blood products that pose the minimum possible risk to the patients who receive them; and

Taking into account that the risk of transfusion-transmitted infections is higher when blood products come from remunerated or replacement donors, rather than volunteer, nonremunerated, and repeat donors,

\section{RESOLVES:}

1. To urge Member States to:

(a) give higher priority in their national health policies to the safety of blood for transfusion

(b) promote the development of national blood programs and transfusion services, based on the voluntary, nonremunerated, and repeated donation of blood, as one indicator of the human development of the population, and on quality assurance;

(c) strengthen the national blood bank infrastructure in order to implement the national blood programs;

(d) ensure the appropriate allocation and efficient use of resources for the acquisition of safe blood products and their use in the population that needs them; ensure training of medical providers in appropriate clinical use of blood products.

2. To request that the Director:

(a) cooperate with the Member States in strengthening the national blood programs and transfusion services, with the collaboration of international institutions, especially in the mobilization of financial resources;

(b) assist in the strengthening of national programs for voluntary, nonremunerated, repeated blood donation;

(c) establish regional standards for the quality of blood banks and transfusion services, as well as for the blood products used in transfusions;

(d) promote universal, accurate, and efficient screening of the units of blood donated in the Region;

(e) document the progress of the national blood programs. 